\title{
Evaluation of Factor Analysis for Chickpea
}

\author{
Vishakha Tiwari*, D.P. Singh and R.R. Saxena \\ Indira Gandhi krishi Vishwavidyalaya, Raipur (C.G.), India \\ *Corresponding author
}

\section{Keywords}

Chickpea, Factor analysis

Article Info

Accepted:

20 January 2019

Available Online:

10 February 2019

\section{A B S T R A C T}

The correlation coefficients may complete information on the relationship between different traits and not to provide benefits according to several multivariate statistical analyses to understand the deep structure of data, factor analysis can be used. Factor analysis techniques used for the main purpose consists of data reduction, summarization of data and represent observed variables using a small number of factors. In order to assess this potential performance yield of Chick pea in different environmental condition and review some of the character associated with yield and some selected superior genotypes, 14 genotypes of Chickpea with studies in various locations in Chhattisgarh during 2015-16 crop year. The analysis of variance showed significant differences between the characters evaluated. Also among genotypes in terms of days of maturity, branches/plant, No. of pod / plant, seed weight and there was a significant difference in yield.

\section{Introduction}

Chickpea is the third most important pulse crop in the world, representing 14\% of total world pulse production (Kelley et al., 1994). Chickpea is grown on 700,000 ha in Iran and ranks fourth in the world after India, Pakistan and Turkey. It occupies about $64 \%$ of the areas grown to food legumes in the country, which is $5.1 \%$ chickpea growing area in the world and produces $2.75 \%$ of global production. Chickpea with $17-24 \%$ protein and $41-50.8 \%$ carbohydrates is one of the most important food crops (Witcombe and Erskine, 1984; Zali et al., 2011). However, high yield is often associated with decreased yield stability (Calderini and Salfer, 1999; Padi, 2007).
The extent of genetic variability has been considered as an important factor which is an essential pre-requisite for a successful hybridization aimed at producing high yielding progenies (Singh and Chowdhury, 1985; Akhtar and Chowdhary, 2006; Dehghani and et al., 2008). Factor analysis has been successfully applied to sort out most influential parameters and to identify the fundamental factors that govern the character of the plant. To establish variation in the chickpea genotype according to their plant character and regular monitoring programs are required.

\section{Objective}

To describe variability among observed, correlated plant characters in Chickpea. 
To examine and determine the effect of plant characters in Chickpea yield.

\section{Materials and Methods}

Fourteen genotypes collected from six sampling sites of Chhattisgarh were analysed chickpea for factor analysis, box plot graphical presentation of data, instability analysis: mean and coefficient of variation.

\section{Study areas}

This study was carried out to determine the yield performances of chickpea genotypes. Among fourteen genotype of chickpea selected were in six environment for the year 2015-2016. Yield data was collected according to the practices of the respective farmer (co-operator) at each site. Chickpea were collected from 6 sites as mentioned namely Jagdalpur, Bhatapara, Bemetra, Kawardha, Korea and Raipur.

\section{Statistical analysis of data}

\section{Box plot}

A box plot shows the fivenumber summary of the data - the minimum, first quartile, median, third quartile, and maximum. An outlier box plot is a variation of the skeletal box plot that also identifies possible outliers. Box plot need to study the characteristics of a single group of numbers, observations, or measurements, to know the centre and the spread about this central value, to investigate extreme values (referred to as outliers) or study the distribution or pattern of the data values.

\section{Instability analysis: mean and coefficient of} variation

To measure the instability in plant characters of Chickpea in different districts, the coefficient of variations (CV) was worked out,

$\mathrm{CV}=($ Standard deviation $/$ mean $) * 100$

\section{Factor analysis}

Factor analysis is a multivariate analysis method which aims to explain the correlation between a large set of variables in terms of a small number of underlying independent factors. It is assumed that each of the variables measured depends upon the underlying factors but is also subject to random errors.

The principal factor analysis method explained by Harman (1976) was followed in the extraction of the factor loadings. The array of communality, the amount of the variance of a variable accounted by the common factors together, was estimated by the highest correlation coefficient in each array as suggested by Seiller and Stafford (1985).

The number of factors was estimated using the maximum likelihood method of Rao (1952). The factor loadings of the rotated matrix, the percentage variability explained by each factor and the communalities for each variable were determined.

\section{Results and Discussion}

\section{Box Plot}

Box plot is the graphical representation of different character of chickpea grain yield of different location. In Raipur highly contribution of character six (Fig. 1), In Bemetara, highly contribution of character $1^{\text {st }}$ (Fig. 2), In Jagdalpur highly contribution of character $2^{\text {nd }}$ Figure 3, In Korea highly contribution of character 5 (Fig. 4), In Kawardha highly contribution of character 5 
(Fig. 5) and In Bhatapara highly contribution of character 5 (Figure 6). On comparison of different location character $5^{\text {th }}$ mostly contribute in the grain yield of different chickpea genotype.

Instability analysis: Mean and coefficient of variation

Days to flower Character shows a high variation (23.8) in Bemetra district. Days to maturity shows high variation $(8.8 \%)$ in
Jagdalpur district. Plant height shows high variation (20.8\%) in Bemetra district. Branches per plant show high variation in Jagdalpur, Korea, Kawardha and Bemetra.

No of pods per plant shows variation in Jagdalpur, Kawardha and Bemetra. Mainly branches per plant and no of pods per plant responsible for variation in seed yield of chickpea genotype for different locational trail (Table 1).

Table.1 Mean and coefficient of variation for different plant character of chickpea crop

\begin{tabular}{|c|c|c|c|c|c|c|c|c|c|c|c|c|}
\hline \multirow{2}{*}{$\begin{array}{l}\text { Plant } \\
\text { Character }\end{array}$} & \multicolumn{2}{|c|}{ Raipur } & \multicolumn{2}{|c|}{ Jagdalpur } & \multicolumn{2}{|c|}{ Korea } & \multirow{2}{*}{$\begin{array}{c}\text { Bhatapara } \\
\text { Mean }\end{array}$} & \multirow[b]{2}{*}{$\begin{array}{l}\mathrm{CV} \\
(\%)\end{array}$} & \multirow{2}{*}{$\begin{array}{c}\text { Kawardha } \\
\text { Mean }\end{array}$} & \multirow[b]{2}{*}{$\begin{array}{l}\mathrm{CV} \\
(\%)\end{array}$} & \multirow{2}{*}{$\begin{array}{c}\text { Bemetra } \\
\text { Mean }\end{array}$} & \multirow[b]{2}{*}{$\begin{array}{l}\mathrm{CV} \\
(\%)\end{array}$} \\
\hline & Mean & $\begin{array}{l}\mathrm{CV} \\
(\%)\end{array}$ & Mean & $\begin{array}{l}\mathrm{CV} \\
(\%)\end{array}$ & Mean & $\begin{array}{l}\mathrm{CV} \\
(\%)\end{array}$ & & & & & & \\
\hline $\begin{array}{ll}\text { Days } & \text { to } \\
\mathbf{5 0} & \% \\
\text { Flower } & \end{array}$ & 55.5 & 5.68 & 57.7 & 6.6 & 69.2 & 6.2 & 56.8 & 3.7 & 49.7 & 6.3 & 46.4 & 23.8 \\
\hline $\begin{array}{l}\text { Days to } \\
\text { Maturity }\end{array}$ & 97.2 & 3.14 & 88.3 & 8.2 & 110.5 & 6.6 & 91.3 & 2.3 & 93.02 & 2.3 & 109.8 & 4.8 \\
\hline $\begin{array}{l}\text { Plant } \\
\text { Height } \\
\text { (cm) }\end{array}$ & 52.8 & 8.06 & 39.5 & 10.1 & 41.6 & 6.9 & 39.6 & 8.90 & 52.1 & 8.4 & 59.1 & 20.8 \\
\hline $\begin{array}{l}\text { Branches/ } \\
\text { Plant }\end{array}$ & 3.1 & 14.77 & 2.7 & 19.7 & 4.4 & 26.1 & 2.6 & 6.27 & 9.7 & 24.6 & 4.3 & 20.6 \\
\hline $\begin{array}{l}\text { Number } \\
\text { of Pods / } \\
\text { Plant }\end{array}$ & 54.1 & 18.35 & 21.1 & 17.1 & 73.9 & 17.8 & 35.7 & 9.7 & 33.2 & 20.8 & 37.4 & 29.5 \\
\hline $\begin{array}{l}100 \text { Seed } \\
\text { Weight } \\
\text { (g) }\end{array}$ & 20.8 & 13.08 & 22.2 & 10.1 & 24.0 & 14.7 & 23.9 & 13.0 & 26.02 & 9.6 & 20.7 & 13.3 \\
\hline $\begin{array}{l}\text { Seed } \\
\text { Yield } \\
\text { (Kg/ha) }\end{array}$ & 2123.3 & 7.47 & 1255.5 & 12.7 & 1469.7 & 14.6 & 981.4 & 21.8 & 1692.2 & 16.1 & 1855.7 & 23.0 \\
\hline
\end{tabular}


Table.2 Factor analysis of different plant character of chickpea crop

\begin{tabular}{|c|c|c|c|c|c|c|c|c|c|c|c|c|c|}
\hline \multirow[t]{2}{*}{$\begin{array}{l}\text { Plant } \\
\text { Character }\end{array}$} & \multicolumn{2}{|c|}{$\begin{array}{c}\text { Component } \\
\text { (Raipur) }\end{array}$} & \multicolumn{2}{|c|}{$\begin{array}{c}\text { Component } \\
\text { (Korea) }\end{array}$} & \multicolumn{2}{|c|}{$\begin{array}{l}\text { Component } \\
\text { (Jagdalpur) }\end{array}$} & \multicolumn{2}{|c|}{$\begin{array}{l}\text { Component } \\
\text { (Bhatapara) }\end{array}$} & \multicolumn{2}{|c|}{$\begin{array}{l}\text { Component } \\
\text { (Kawardha) }\end{array}$} & \multicolumn{3}{|c|}{$\begin{array}{l}\text { Component } \\
\text { (Bemetara) }\end{array}$} \\
\hline & PC 1 & PC 2 & PC 1 & PC 2 & PC 1 & PC 2 & PC 1 & PC 2 & PC 1 & PC 2 & PC 1 & PC 2 & PC 3 \\
\hline $\begin{array}{l}\text { Days to } 50 \\
\% \text { Flower }\end{array}$ & 0.84 & 0.28 & 0.92 & 0.18 & 0.79 & 0.37 & -0.22 & 0.05 & 0.66 & -0.29 & - & 0.99 & \\
\hline $\begin{array}{l}\text { Days to } \\
\text { Maturity }\end{array}$ & 0.88 & 0.35 & 0.92 & 0.13 & 0.81 & 0.35 & -0.14 & 0.04 & 0.22 & -0.51 & 0.82 & -0.15 & 0.18 \\
\hline $\begin{array}{l}\text { Plant } \\
\text { Height } \\
(\mathrm{cm})\end{array}$ & 0.27 & 0.83 & 0.72 & -0.41 & 0.66 & - & 0.26 & 0.42 & -0.11 & 0.49 & 0.99 & & \\
\hline $\begin{array}{l}\text { Branches/ } \\
\text { Plant }\end{array}$ & 0.88 & - & - & 0.89 & - & 0.79 & 0.01 & 0.001 & -0.06 & 0.06 & -0.32 & 0.28 & \\
\hline $\begin{array}{l}\text { Number of } \\
\text { Pods / } \\
\text { Plant }\end{array}$ & 0.18 & 0.46 & 0.14 & -0.89 & - & 0.85 & -0.34 & 0.72 & -0.29 & -0.48 & 0.18 & & 0.98 \\
\hline $\begin{array}{l}100 \text { Seed } \\
\text { Weight (g) }\end{array}$ & - & 0.90 & 0.12 & 0.60 & 0.65 & -0.11 & 0.69 & -0.144 & -0.15 & 0.26 & 0.35 & -0.53 & -0.38 \\
\hline $\begin{array}{l}\text { Eigen } \\
\text { values }\end{array}$ & 2.92 & 1.41 & 2.95 & 2.18 & 2.59 & 1.23 & 2.51 & 1.41 & 2.70 & 1.48 & 2.53 & 1.85 & 1.21 \\
\hline $\begin{array}{l}\% \text { of } \\
\text { variance by } \\
\text { component }\end{array}$ & 48.67 & 23.61 & 38.24 & 36.35 & 43.18 & 29.57 & 51.48 & 23.81 & 56.88 & 21.40 & 44.10 & 30.97 & 22.96 \\
\hline $\begin{array}{l}\text { Cumulative } \\
\% \text { of } \\
\text { variance }\end{array}$ & 48.67 & 72.29 & 38.24 & 74.59 & 43.18 & 72.75 & 51.48 & 75.83 & 56.88 & 78.21 & 44.10 & 75.07 & 98.04 \\
\hline
\end{tabular}

Fig.1 Boxplot of different plant character of Raipur

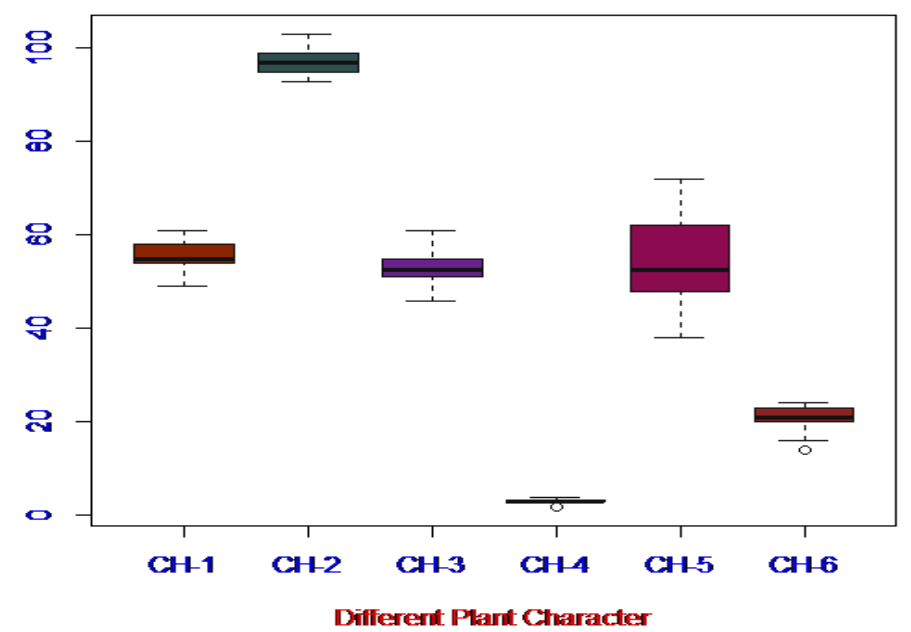


Fig.2 Boxplot of different plant character of Bemetara

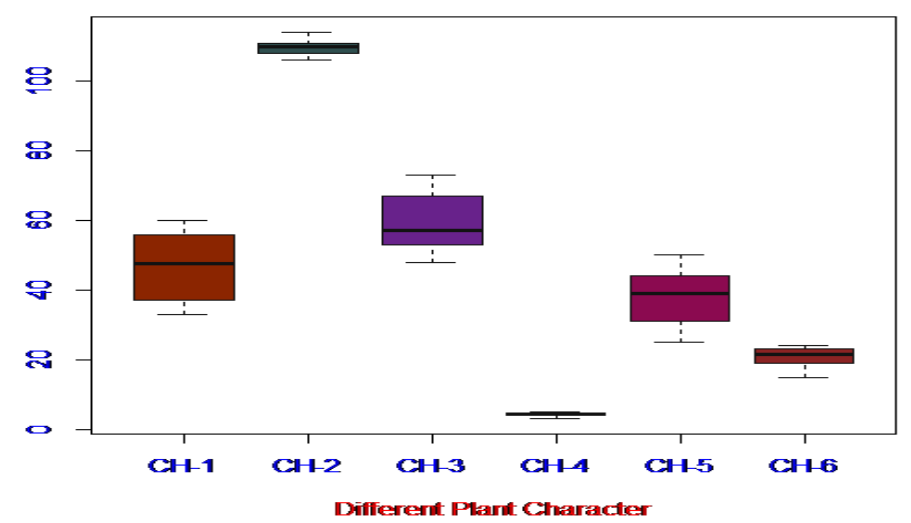

Fig.3 Boxplot of different plant character of Jagdalpur

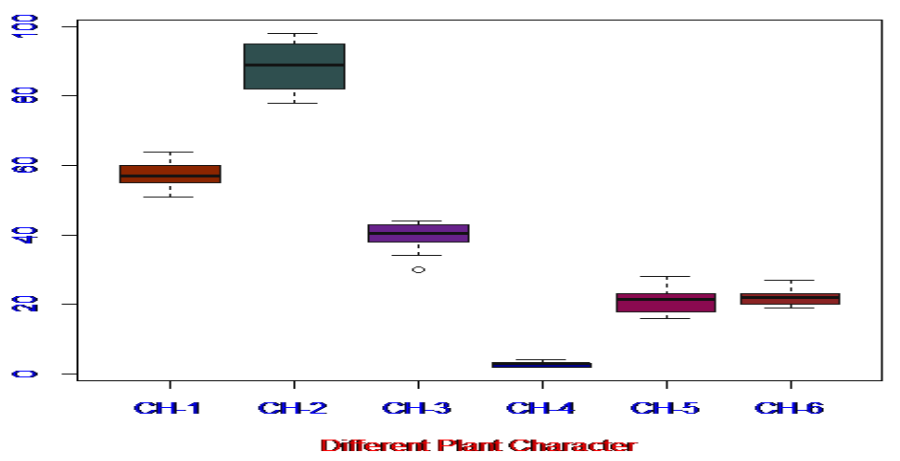

Fig.4 Boxplot of different plant character of Bhatapara

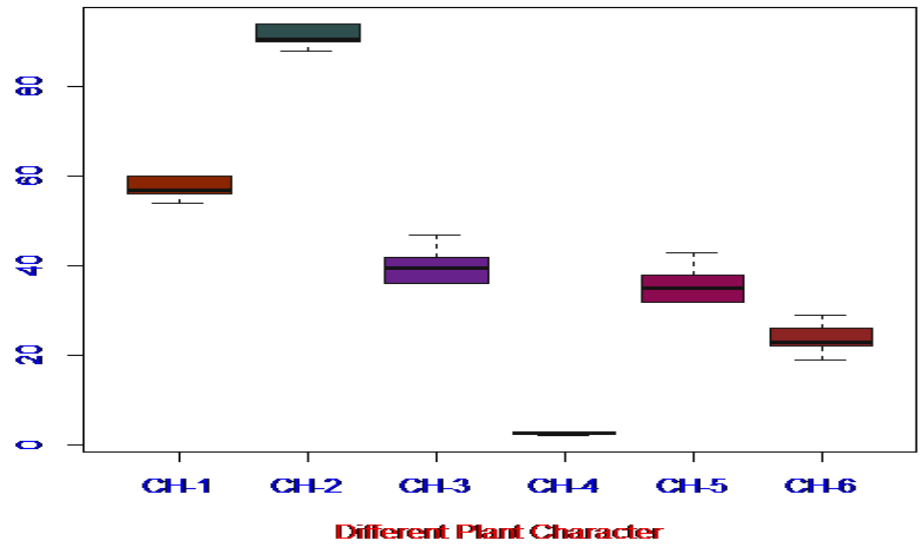


Fig.5 Boxplot of different plant character of Kawardha

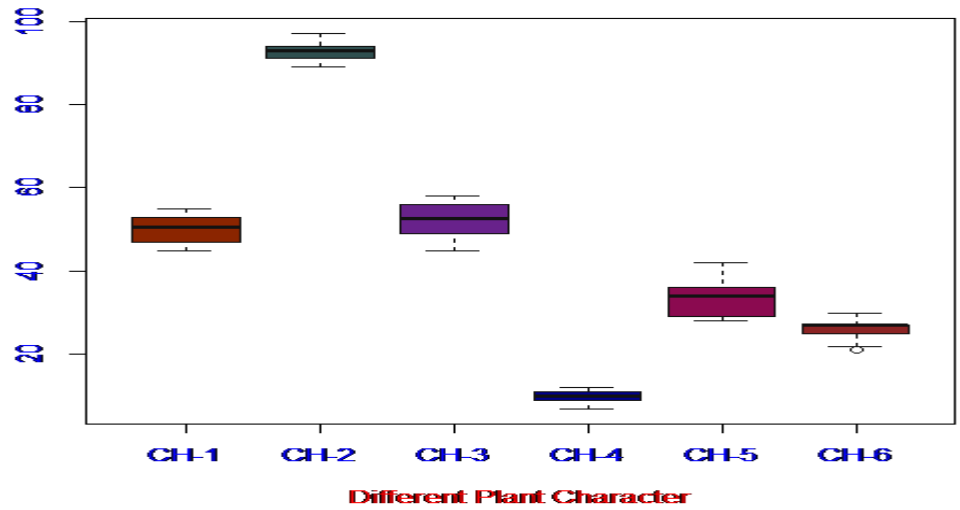

Fig.6 Boxplot of different plant character of Korea



Fig.7a

Fig. $7 b$
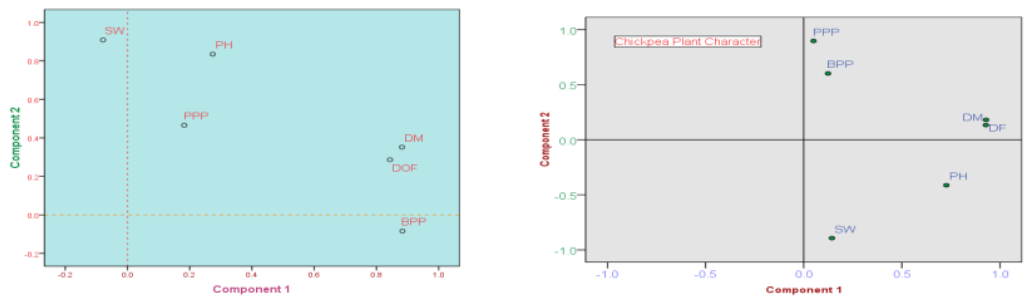

Fig 2.1 factor analysis of Raipur

Fig 2.2 : factor analysis of korea 
Fig.8a

Fig.8b
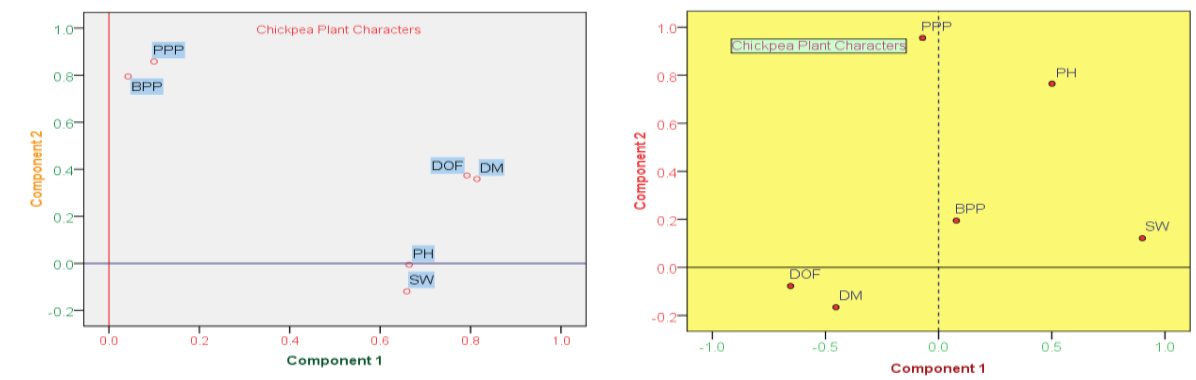

Fig2.3 factors analysis of Jagdalpur
Fig.9a

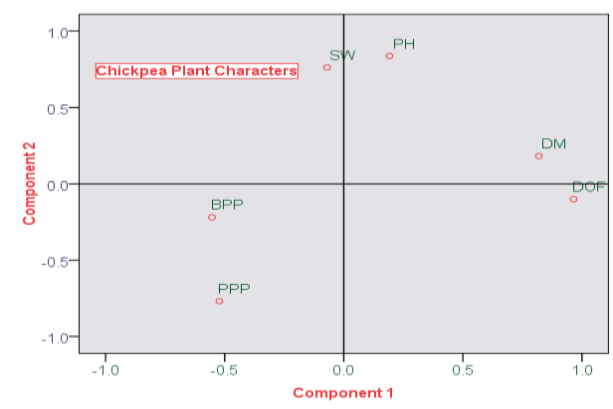

Fig 2.5 Factor analysis of Kawardha
Fig.9b

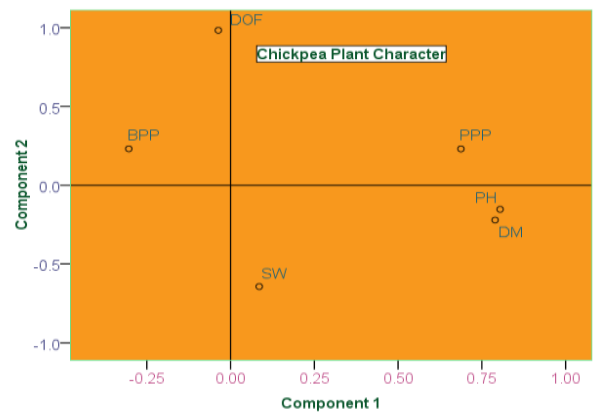

Fig 2.6 Factor analysis of Bemetra

\section{Factor analysis}

PC1 of Raipur district character / factor days to $50 \%$ flower, days to maturity and branches/maturity mainly contributes for total variance explained $(72.30 \%)$ in seed yield. PC1 of Korea district character / factor days to $50 \%$ flower, days to maturity mainly contributes for total variance explained $(74.50 \%)$ in seed yield. PC1 of Jagdalpur 
district character / factor days to $50 \%$ flower, days to maturity mainly contributes for total variance explained $(72.75 \%)$ in seed yield. PC1 of Bhatapara district character / factor no of pods per plant mainly contributes for total variance explained $(75.29 \%)$ in seed yield. PC1 of Kawardha district character / factor days to $50 \%$ flower mainly contributes for total variance explained $(78.28 \%)$ in seed yield. PC1 of Bemetara district character / factor days to maturity, plant height mainly contributes for total variance explained $(98.03 \%)$ in seed yield (Fig. 7-9 and (Table $1)$.

The factor which mostly contributes days to maturity, days to $50 \%$ flower for seed yield of all location trail.

\section{References}

Asfaw T, Geletu B, Alem B. 1994. Role of cool season food legumes in Ethiopia. Pp. 3-18. In: Asfaw T, Saxena M, Solh M, Geletu B. (Eds.) Cool season food legumes of Ethiopia. Proceedings of the First National Food legumes Conference, 16-20 December 1993,
Addis Ababa, Ethiopia.

Ethiopian Central Statistical Authority (CSA).1998. Agricultural sample survey, area and production of major crops. Statistical Bulletin 189.

Harman HH. 1976. Modern factor analysis, $3^{\text {rd }}$ Ed. University of Chicago Press, Chicago.

Rao CR. 1952. Advanced statistical method in biometric research. John Wiley and Sons, New York.

Seiller GJ and Stafford RE. 1985. Factor analysis of components in Guar. Crop Sci. 25, 905-908.

Thulin M. 1983. Leguminosae of Ethiopia. Opera Bot. 68, 1-23.

Vavilov NI. 1951. The origin, variation, immunity and breeding of cultivated plants. Chron Botan 13, 1-36.

Walton PD. 1972. Factor analysis of yield in spring wheat (Triticum aestivum L.). Crop Sci. 12, 731-733.

Woldeamlak A, Alelign K. 1990. Status of grasspea (Lathyrus sativus) production in Ethiopia. IAR Newsletter of Agricultural Research (Ethiopia) Vol. 5. Addis Ababa

\section{How to cite this article:}

Vishakha Tiwari, D.P. Singh and Saxena, R.R. 2019. Evaluation of Factor Analysis for Chickpea. Int.J.Curr.Microbiol.App.Sci. 8(02): 2856-2863.

doi: https://doi.org/10.20546/ijcmas.2019.802.335 